memoir on this subject, that of L. Frédéricq*, on the muscles of the lantern of Echinus sphara, their striation is again denied. How are we to explain this utter confusion?

By treating the muscles of the Urchin with different reagents and making a considerable number of preparations we have seen all the phenomena described by these authors. Frequently the adductor muscles of the valves of the pedicellariæ are distinctly striped; frequently also they do not show the least trace of striation. The same fact may be observed with the muscles of the lantern ; for we have preparations which contain the simple fibres of Wagner and Frédéricq side by side with others of which the striation is as evident as in Valentin's drawings. Moreover by passing along a single fibre we very frequently find all possible gradations between the most distinct striation and its complete absence.

Our colleague, Mr. Haycraft, has just proposed a new theory upon the structure of the voluntary muscles $\uparrow$. In his view the fibrils are not simple cylinders, but they are slightly constricted at small intervals; and he asserts that their striation does not indicate a histological differentiation, but is simply an optical phenomenon produced by the unequal refraction that the light undergoes in traversing the fibril.

Without wishing to pronounce an opinion upon this theory from a general point of view, and without affirming that the striation of the muscles of the Echinodermata is due to the same cause as that of the muscles of the higher animals, we are convinced that the irregularity of the striation in the Echinus may be explained in the same way.

The fibres of the lantern show constrictions in perfect correspondence with the transverse strix; when these constrictions follow one another very rapidly the striæ also approach each other; and when they become more widely separated the striæ show the same irregularity. Lastly the striæ and the constrictions disappear together.

It is probable, as has already been suspected, that the striation stands in some relation to the state of contraction of the muscles; but we hope to make fresh observations before pronouncing an opinion upon this question.-Comptes Rendus, February 7, 1881, p. 308.

\title{
On the Formation of the Blastoderm in the Araneida.
}

By M. A. Sabatier.

The mode of formation of the blastoderm in the Araneida has given rise only to a small number of publications, the data and conclusions of which are contradictory. The phenomenon presents two distinct phases : the first terminates in converting the egg into a meroblastic ovum with multiple cicatriculæ; the second includes the discoidal segmentation of each of the cicatriculæ, so as to form a simple and continuous layer of blastodermic cells.

* Arch. de Zool. Expér. 1877.

† Proc. Royal Soc., February 1881. 
The ovum, examined two or three hours after deposition, consists of a network of granular protoplasm, in the meshes of which are contained the spheres of the deutoplasm. The surface of the ovum is covered by a continuous layer of protoplasm, a layer the existence of which Ludwig has erroneously denied, and which he has confounded with the chorion covered with projecting granules. This layer divides very clearly into germinative areas, as was first described by Balbiani; and, notwithstanding the contrary assertions of Ludwig and Barrois, I have been able to grasp the mode of formation of this division, and to ascertain that it has a significance different from that ascribed to it by Balbiani. It is due to the transference of the protoplasm from the interior to the surface of the ovum. Hyaline protoplasm gushes forth in the intervals of the vitelline spheres of the surface, and divides the granular layer. This phenomenon has no particular influence upon the formation of the blastodermic cells. It is the result of a centrifugal tendency of the protoplasm, which governs the first phases of development in the Araneida.

A few hours after this division there appear at the surface of the ovum at first large, diffused, deep spots, and soon afterwards dark stellate figures, described by Balbiani, and surrounded by the brilliant rosettes of Ludwig. The dark stellate forms are true salient disks of granular protoplasm, having a large pale nucleus in their centre. Sections made at this moment show that the disks issue from trains or dissepiments of the same nature, which separate and englobe the neighbouring vitelline spheres.

In ova taken before the formation of the rosettes of the surface I have never ascertained the existence of the cylinders of deutoplasm, or "Deutoplasmasäulen" of Ludwig, in the interior of the ovum itself; and I do not think that we can adopt the opinions of that author as to the mode of segmentation of the ovum by the successive splitting of the central rosettes. What is really the case is that the protoplasm grouped around the nuclei moves from the interior towards the surface, drawing more and more towards it the protoplasm of the dissepiments, and producing first of all diffused spots, which become resolved into dark superficial rosettes.

From the examination of sections it appears :- 1 . That the granular protoplasm, at first diffused pretty uniformly in the form of a network between the spheres of deutoplasm, bears more and more towards the periphery of the ovum, at the same time concentrating around a small number of nuclei. 2. That the masses of protoplasm appear at the surface in the form of dark lenticular masses or disks, from which issue rays of the same substance, which separate the surrounding vitelline spheres and envelop them in the form of partitions. It is to the thickness of the interposed dark septa, and very probably also to the centripetal contraction of these septa, that these vitellne spheres owe the very strongly-marked appearance of their contours and the elongation of their axis towards the centre of the dark disk, conditions which produce the phenomenon of the brilliant rosettes of Ludwig. But these rosettes can only exist at 
the surface of the ovum, and when the dark masses and the dissepiments have attained a sufficient concentration. The central rosettes, or large rosettes of Ludwig, are purely imaginary phenomena, assumed (rather than observed) in accordance with an illegitimate analogy between the phenomena witnessed at the surface of the ovum and those which are supposed to take place in its depths.

To sum up, the protoplasm, in the Araneida, moves from the centre towards the periphery, where it makes its appearance in the form of disks or cones of ejection, surrounded by the spheres of the rosette, which may be compared to cones of elevation. There is eruption through a chimney, which subdivides towards the centre of the ovum. By this means the ovum is transformed into a meroblastic ovum with multiple cicatriculæ. This is the end of the first phase.

During the second phase the regular meroblastic segmentation of the cicatriculæ takes place. The nuclei divide, and with them the dark stellate forms, and the rosettes of Ludwig. In this way is produced a second generation of stars and rosettes. As this goes on the granules and the protoplasm of the germinative areas are attracted by the dark disks, which finally absorb them entirely. In the third generation the brilliant rosettes cease to be visible, which is due to the disappearance of the thick dissepiments of protoplasm and their absorption into the dark disks.

The protoplasm of the surface continues segmenting, and finally forms a single layer of flattened polygonal cells. This is the blastoderm, which covers the whole surface of the ovum.

In none of the species that I have studied have I found the central cavity or blastocœle, any more than the radial orientation of the vitelline masses, such as are described and figured by Ludwig.

From these observations it results that the ovum of the Spider presents an intermediate type between the ova with general superficial segmentation of the Crustacea, such as Peneus, and the ova with regular discoidal segmentation, such as those of certain fishes; that is to say, it has a blastulation intermediate between periblastulation and discoblastulation. It greatly approaches the ova of Chelifer (Metschnikoff), Tetranychus (Claparède), and of insects (Bobretzky). Thus is plainly manifested from the outset the affinity of the Araneida with other groups of Arachnida and with the insects.

My observations have been made upon the ova of Pholcus opilionides, Epëra diadema, Epëra fasciata, Agelena labyrinthica, Latrodectus malmignatha, and some small undetermined species.-Comptes Rendus, January 24, 1881, p. 200.

\section{Acineta dibdalteria, a new Species of Marine Infusorian from the Gulf of Genoa. By Dr. Conrad Parona.}

When seeking Protista at Sestri Levante(Riviera di Genova) and in the sea-water that I had brought home with me for subsequent study, I found last September a new Acinetine, which struck me by its very peculiar characters, and especially by the suckers, which are not borne by a trunk and are not ramified. 


\section{$2 \mathrm{BHL}$ Biodiversity Heritage Library}

Sabatier, Armand. 1881. "On the formation of the blastoderm in the Araneida." The Annals and magazine of natural history; zoology, botany, and geology 7, 277-279. https://doi.org/10.1080/00222938109459512.

View This Item Online: https://www.biodiversitylibrary.org/item/79589

DOI: https://doi.org/10.1080/00222938109459512

Permalink: https://www.biodiversitylibrary.org/partpdf/62397.

\section{Holding Institution}

Smithsonian Libraries

\section{Sponsored by}

Smithsonian

\section{Copyright \& Reuse}

Copyright Status: Public domain. The BHL considers that this work is no longer under copyright protection.

This document was created from content at the Biodiversity Heritage Library, the world's largest open access digital library for biodiversity literature and archives. Visit BHL at https://www.biodiversitylibrary.org. 